\title{
Hunger and food security in the times of Covid-19
}

\author{
Dipa Sinha ${ }^{1}$
}

Accepted: 25 October 2020 / Published online: 15 February 2021

(c) Institute for Social and Economic Change 2021

\begin{abstract}
This paper discusses the situation of hunger and malnutrition in India during the times of the Covid-19, the associated lockdown and the aftermath. The economic slowdown and loss of employment have resulted in widespread food insecurity. There are also concerns that this might have long-lasting effects on the nutrition status of the population. In this context, government support through schemes such as the PDS plays an important role. While there have been some interventions through these schemes towards providing food and cash support to people, there are many gaps. The availability of high food stocks can be used as an opportunity to provide a universal PDS which is the need of the hour. Other issues such as expanding the PDS to include pulses and oils, decentralised procurement, universal food support through school meals and ICDS, and enhanced cash transfers through social security schemes also need to be ensured.
\end{abstract}

Keywords Covid-19 $\cdot$ Lockdown $\cdot$ PDS $\cdot$ Food security $\cdot$ Hunger $\cdot$ Malnutrition

The global novel coronavirus pandemic and the ensuing economic slowdown have led to rising concerns of food insecurity across the world. Quarantine requirements, social distancing norms, lockdowns, border closing, etc., have disrupted supply and distribution networks making the availability and accessibility of food uncertain. Loss of livelihoods due to the associated economic distress has made it more difficult for people in the informal sectors and in precarious occupations to meet their basic needs. The World Bank has estimated that 71 million people will fall be pushed into extreme poverty across the globe as a result of the pandemic (World Bank 2020). The UN has stated that we are facing an impending food emergency and the World Food Programme estimates that an additional 130 million people could fall into the category of being food insecure over and above the 820 million who were so classified by the State of Food Insecurity in the World Report, 2019 (United Nations 2020).

In India too, the Covid-19 pandemic and the national lockdown have led to a loss of livelihoods and has added to the demand depression that the country was already facing. The situation of the poor in the country was worsening even in the period before the lockdown with stagnant rural wages and unemployment at its highest. The pandemic and the

Dipa Sinha

dipa@aud.ac.in

1 School of Liberal Studies, Ambedkar University Delhi, New Delhi, India 
lockdown have exacerbated the precarity of lives and livelihoods for many across the country. After the lockdown was announced on 24 March, the migrant crisis was immediately visible with thousands of migrants walking on the highways trying to get back to their homes. While many governments responded with provision of cooked food at feeding centres, and NGOs/civil society organisations also contributed to the relief efforts across the country, the scale of the problem has been massive.

Although there are no official data available on the situation of hunger in the country, after the pandemic, a number of media reports and research studies conducted by independent organisations show that there has been a devastating impact on incomes, employment and food security. A study conducted by the Centre for Sustainable Employment, Azim Premji University, through phone interview across 12 states covering about 5000 households found that $77 \%$ households were consuming less food than before and $66 \%$ lost employment (Lahoti et al. 2020). Another study conducted by the Centre for Equity Studies found in their sample that only 38.9\% (547) said that they never went completely out of food during the lockdown. Further, many among those who reported never having gone without food reported that they have diminished their intake and were often having one meal in a day (Centre for Equity Studies 2020). Gupta et al. (2020) report that a survey commissioned by them of 47,000 households found that "the average family has lost more than $60 \%$ of its pre-crisis income". A group of volunteers maintained a list of all non-covid reported deaths (i.e. deaths that are reported in the newspaper) which can be attributed to the lockdown, and they documented almost 300 deaths during this period that were due to starvation and financial distress. ${ }^{1}$ These micro-evidence does not seem out of place when we take into account the fact that the economy contracted by $24 \%$ in the April to June quarter compared to the same period last year. The IMF has estimated that the rate of change based on the 2020 Projected Real GDP for India would be $-10.3 \%$. $^{2}$

Economists have been arguing that the economy will take some time for revival, even though the lockdown has now been lifted (Sen 2020). Supply chains have been disrupted, and many operations that were completely shut have been unable to restart. The general demand slump in the economy due to lack of purchasing power also means that investments are not forthcoming (Ramakumar 2020). This is further exacerbated by the fact that the number of covid-positive cases in India continues to rise and there is no clarity on what the disease progression will be like. A number of countries in Europe are facing a second wave, and with upcoming cold temperatures especially in North India, there are concerns that India has not yet reached its peak. This also results in a macroeconomic dilemma on when and how much the government should spend on reviving the economy through stimulus. Moreover, any demand stimulus requires a huge amount of spending by the government which is bound to put a strain on the fiscal resources given the current situation where revenues from taxation (including GST) have been lower and the government has already spent a substantial amount on the Atmanirbhar package.

The longer-term effect of people's food consumption being affected badly could be on situation of malnutrition in the country, especially among children. While there have been some improvements in the overall indicators of malnutrition in India in the last decade or so, the levels of hunger and malnutrition are still very high. According to the NFHS-4 data (2015-16), 38\% of children under five are stunted (low height for age representing

\footnotetext{
${ }^{1}$ https://thejeshgn.com/projects/covid19-india/non-virus-deaths/.

2 https://www.imf.org/en/Countries/IND.
} 
chronic undernutrition) and $20 \%$ of children are wasted low weight for height representing acute malnutrition). More than half women and children are anaemic (IIPS 2017). The last few years also saw reports of hunger-related deaths from different parts of the country (Alam 2020). Therefore, inadequate diets, poor nutrition and pockets of starvation were already prevalent. In this context, it is obvious that having even fewer opportunities for employment as well as having to face the restrictions placed by the lockdowns would have had an impact on the food security of people. Along with this, the closure of a number of public programmes such as the anganwadis and schools (mid-day meal schemes), which supported people's access to food, nutrition and health services has also made many, especially women and children, vulnerable to malnutrition.

This paper focusses on the response of the central government in India to this situation of hunger and malnutrition. A brief introduction to the welfare schemes in India is provided followed by an analysis of what has been done so far, while highlighting the gaps that remain. The main response to food security has been through the Public Distribution System (PDS), and therefore, this is looked at in some detail. Since the discussion is mostly related to the very recent period, official data or research studies are not yet available. The paper is therefore based on an analysis of government data on implementation of schemes wherever available, newspaper reports and the author's own experience as a member of the Right to Food campaign which has been involved in relief and advocacy work across the country. ${ }^{3}$ Although there are these limitations, it is hoped that this article can contribute to raising some relevant issues related to the food systems in India which need immediate attention and also provide some pointers on future areas of research.

\section{Role of India's Welfare Architecture}

The sudden onset of the lockdown created a crisis of stranded workers almost overnight. As seen across the world, support measures by governments to help people wade through the pandemic-induced distress were imperative. In this context, the existing welfare architecture in the country plays an important role. This crisis and the response are also be an opportunity to review the role of social welfare schemes and entitlement-based legislations in India.

The period 2005-10 saw the introduction of a number of legislations that protected and promoted people's entitlements to land, employment, education and so on. The National Rural Employment Guarantee Act (NREGA) promised 100 days of work on demand to every rural household. The Right to Education Act (RTE) guaranteed access to elementary schooling to every child. This period also saw some focus on provision of primary education and health care by the government through the Sarva Siksha Abhiyan, followed by the RTE and the National Rural Health Mission (NRHM). Largely due to interventions of the Supreme Court in the Right to Food case, there was also an expansion in the PDS, universalisation of cooked mid-day meals in schools and universalisation of early childcare services through the Integrated Child Development Services (ICDS). Pension given under the National Social Assistance Programme (NSPA) was more than doubled from Rs. 75

\footnotetext{
3 The Right to Food campaign is also involved in conducting a survey called 'Hunger Watch' interviewing vulnerable households on the situation of food security which is just completed and the data are being cleaned and analysed. The author is one of the co-ordinators of this survey.
} 
per month to Rs. 200 per month and disabled persons and single women were also added as beneficiaries along with old persons (Joshi et al. 2017; Hertel 2015).

While discussions started in 2009, the National Food Security Act (NFSA) was also passed after 4 years in 2013. The NFSA converted into legislated entitlements a number of orders of the Supreme Court mentioned above and laid out a framework for an expanded PDS which went beyond the consumption expenditure-based poverty line. While there exist many gaps in implementation, a number of field studies also show that many a times these schemes are a lifeline for the poor-the meagre pension allows old people to buy food and medicines, children to eat at least one full nutritious meal a day, adults to access employment during lean seasons and so on (Drèze and Khera 2017). In fact, it can be argued that these schemes, especially the PDS and NREGA, made the impact of the 2008 global economic crisis less severe on the poor in India by providing a social safety net.

However, there continue to be reports that these schemes are underfunded and in need of reforms. ${ }^{4}$ For example, the central contribution to pensions under NSAP has remained Rs. 200 per beneficiary per month since 2006. Similarly, there are issues related to wages of anganwadi workers, inadequate infrastructure, insufficient funds for supplementary nutrition and so on. On the other hand, there are also arguments about these schemes leading to wasteful expenditure, being inefficient and suffering from leakages. Although the need for additional funding has not been taken into consideration, the focus has shifted to 'direct benefit transfers (DBT)', linked to the aadhaar platform. On the one hand, aadhaar linking is seen as the on-size-fits-all solution to leakages in the schemes, and on the other, there is a general consensus building that all these schemes are 'subsidies' and hence a drag on the growth potential of the economy. Most of these schemes have hence seen declining or stagnant budgetary support. Mandatory aadhaar seeding in all these schemes created disruption with new forms of exclusions being seen (Khera 2017).

The current crisis has brought to the fore the significance of this welfare architecture in providing social security to people. The relief measures announced so far by the government under the PMGKY and the Atmanirbhar Abhiyan use these existing schemes such as the PDS, Jan Dhan, social security pensions, MGNREGA to make additional transfers as well as to provide a temporary cushion. This period has also highlighted the lacunae in these schemes and how they can be strengthened to ensure better human development outcomes. In this background, the following sections analyse the interventions in PDS and child feeding programmes.

\section{Public distribution system}

The NFSA provides $5 \mathrm{kgs}$ of foodgrains (rice/wheat/millets) per head to $75 \%$ of the rural population and $50 \%$ of the urban population at subsidised prices as given in the Schedule of the Act (Rs. 3/kg rice, Rs. 2.kg wheat and Re. 1/kg millets), through the PDS. Based on this, the central government through the FCI allocates foodgrains to the states. The identification of beneficiaries and overall implementation is the responsibility of the state governments. Prior to the NFSA, the quotas given to the state governments depended on the poverty ratios in the state, based on which below poverty line (BPL) households were to

\footnotetext{
${ }^{4}$ See the reports of the Centre for Governance and Budget Accountability on the annual budgets for data on various schemes. These reports are available at https://www.cbgaindia.org/.
} 
be identified. The system of identifying BPL households saw large exclusion and inclusion errors. The present system under the NFSA, where priority households are identified, resulted in much larger coverage than BPL especially in rural areas in poorer states. Because of this, as well as a number of states using the Socio-Economic Caste Census (SECC) which was a better methodology for identification than the earlier BPL Census, it is perceived that there has been an improvement in inclusion of households under the PDS. Under the Act, some governance reforms also took place in PDS in most states. This also contributed to making the implementation of PDS better in erstwhile lagging states such as Bihar (Drèze and Khera 2015). More recent nationally representative data that can give trends on the leakages and coverage under PDS are not available, especially because the latest consumption expenditure survey of the NSS which is used to make these estimates relates to 2011-12.

Many states such as Tamil Nadu, Andhra Pradesh, Telangana and Chhattisgarh provide subsidised foodgrains to a larger number of households than those are covered under the NFSA. However, there still remain exclusions and these exclusions have become even more noteworthy in the current situation of the pandemic as the relief package of the central government, which included free foodgrains, was only for those persons who are covered under the NFSA. As part of the Pradhan Mantri Garib Kalyan Yojana (PMGKY), the government is now providing additional $5 \mathrm{kgs}$ of grains (and $1 \mathrm{~kg}$ pulses per household) for free to those who have ration cards under the NFSA (for the period April to November 2020). This includes about 81 crore NFSA beneficiaries viz. $60 \%$ of the current estimated population of India, but leaves out the additional state ration card holders as well as those who do not have ration cards (Sinha 2020a). It has been shown that even to fulfil the NFSA requirement of coverage of $67 \%$ population, using updated population estimates of 2020 an additional 10 crore persons need to be covered (Scroll 2020). ${ }^{5}$ Further, the requirement may be much more in the present crisis where many have lost their livelihoods.

Later in May, the Government of India announced that an additional 8 crore migrant workers who do not have ration cards will be given $5 \mathrm{kgs}$ of free grains and $1 \mathrm{~kg}$ of free dal for two months as part of the Atmanirbhar package (June and July 2020). The data show that the offtake under this scheme has been abysmal with reports showing that only about $13 \%$ of the allocated grains had been distributed under this scheme (Sharma 2020). The main reason for the same is mostly likely because the criteria for identification of these additional beneficiaries have not been laid out. Rather, the Government of India made an allocation of foodgrains for this scheme for each state of an amount which was equivalent to $10 \%$ of their usual NFSA quota. States came up with different mechanisms to identify these additional beneficiaries-e.g. Delhi had a system where people could apply online for an e-coupon using their aadhar numbers, Rajasthan has evolved a system where they try to check whether people have a ration card in another state and therefore can be included in the migrant quota and so on (Johri 2020). Given the urgency of the situation as well as the past experience with mechanisms for identification of eligible beneficiaries which showed that the poor often lack documents and get left out, it is proposed that the better option in the current situation would be to universalise the PDS.

The problem of access to food for those who do not have ration cards is being acknowledged now by more and more state governments. However, what has still not gained wide acceptance is the idea of a universal PDS as a way in which it can be ensured that nobody

5 These estimates were by Jean Dreze, Reetika Khera and Megha Mungikar. 
is left out. There could be some exclusion criteria such as those who are income tax payees, lists of whom the government already has. In fact, it can be safely assumed that such persons would exclude themselves as the opportunity costs of queuing up at fair price shops are too high (Himanshu and Sen 2011).

There are a number of arguments in favour of universalisation of the PDS even under normal circumstances as it has the benefits of ensuring minimal exclusion errors, can reduce leakages as well as contributing to overall food security. For example, in Tamil Nadu, any 'ordinarily resident' household is eligible for a ration card. Research has shown that Tamil Nadu has one of the lowest leakages in PDS along with Chhattisgarh a state which has 'near-universalisation'. Further, it has also been shown that despite universalisation some households in Tamil Nadu choose to opt out of accessing the subsidised grains, and the proportion of households buying PDS grain was around 76\% (Himanshu and Sen 2011).

Another reason that can be stated in favour of expanding the coverage of the PDS as a favoured policy option in the present situation is the amount of stocks that are lying in the godowns of the Food Corporation of India (FCI). Including the unmilled paddy, the foodgrains in the FCI had risen to over 96 million MTs while the buffer stock norms is 41 million MTs for 1st July. While the outgo of foodgrains for a month including the expanded distribution under PMGKY is around 8 million tonnes, it is expected that there will be more foodgrains procured in a few months once the Kharif crop is harvested (49.9 million MTs of rice was the procurement during Kharif Marketing Season in 2019-20). A universalised PDS giving $10 \mathrm{kgs}$ of foodgrains per person per month for 4 months requires about 47 million tonnes in total, assuming about $85 \%$ of the population actually lifts their rations. ${ }^{6}$ Therefore, distributing grains through the PDS with an expanded coverage and higher quantity of grains given per person could be a prudent policy option, especially in the present context of reported economic distress and widespread hunger.

It must be remembered that stocking grains also add to the costs of FCI in terms of the storage costs. It also keeps the grains away from the market which can even have an upward pressure on prices. The other alternatives for this grain are to use the stocks for open market sales or to export them. The government sells grains at prices lower than the procurement cost but much higher than the issue prices under PDS, through the Open Market Sales Scheme (OMSS). Disbursing the grains through this manner also results in a lower fiscal burden compared to distribution through PDS. However, based on the past experience with the OMSS it is seen that very little grain is sold through this process with only 16.6 million tonnes of rice and wheat being sold during the period 2017-18 to 2020-21 (up to first week of June). Not only was the quantity that was sold each year less than the quantity offered for sale but over, one-third of all sales was to state governments (almost all of the rice) thereby shifting the subsidy burden to state governments. ${ }^{7}$ The possibility of exports and the prices that the grain will receive depends on the conditions of the global market and cannot be justified when there are so many people facing food insecurity in the country.

\footnotetext{
${ }^{6}$ Data o foodgrain stocks as available on FCI website (https://fci.gov.in/). The calculation on grains required has been made by the author based on the projected population for 2020 as available in the national accounts statistics released by Government of India.

7 This is based on calculation by the author looking at data on open market sales of paddy, rice and wheat as available in the website of the Food Corporate of India. (https://fci.gov.in/).
} 
The main cause for the reluctance of the government to expand the PDS despite such high stocks seems to be over concerns to contain the fiscal deficit (Dreze 2020). As long as the government does not pay the FCI, although the FCI has already paid the farmers for procuring the grains, this cost does not get reflected in government expenditure. It appears as food subsidy only when it is distributed through the PDS at subsidised prices. In fact, even before the current crisis, the government has been using this route of off-budget accounting by Government of India, to show a lower fiscal deficit. This mismanagement has resulted in the FCI being pushed into a situation of unsustainable debt where it now has an outstanding loan of over Rs. 2.5 lakh crore from the National Small Savings Fund (NSSF). However, the concerns of escalating food subsidy are exaggerated. The data show that the actual food subsidy and the NSSF loan put together still account for less than $1 \%$ of the GDP per annum. Excluding the off-budget borrowings, the food subsidy in the last three years is between 0.53 and 0.59 per cent of GDP, much less than what it was in the years preceding NFSA when it was between 0.8 and 0.85 per cent (Sinha 2020a). ${ }^{8}$

The government's attention is on the One Nation One Ration Card (ONOC) scheme, which is supposed to be completely rolled out by March 2021 as a possible solution to the problem of exclusions. Under ONOC, a beneficiary can get ration entitlements as given under the NFSA from any fair price shop in the country using her/his Aadhaar number and biometric authentication. This is supposed to be possible once the Aadhaar numbers of all members enlisted in ration cards are seeded which will enable the transactions under PDS across the country to be brought on to one digital platform. It was announced that ONOC is yet to be made operational 14 states. $^{9}$

While portability of PDS across states can help migrant workers access their entitlements wherever they are, the ONOC is also riddled with problems which need to be resolved. It depends on making a complete transition of biometric authentication using ePoS machines, the experience of which so far suggests that it results in exclusion of some of the most marginalised because of multiple reasons including network issues, authentication failure and so on. There are also questions related to how the scheme will be implemented in the present situation where there is no uniformity in PDS entitlements across states, a large proportion of migration is of individuals and not entire households and allocations to fair price shops are made on the basis of number of ration cards (Khera, 2020). While there is no space for a detailed discussion on the ONOC, the crucial point to note that this scheme is not in a position to address the immediate crisis of hunger.

The limited role of ONOC currently can be seen in the data on current usage of ONOC scheme. The integrated management of PDS portal ${ }^{10}$ which gives real-time data on transactions under ONOC shows that in the entire month of May there were a total of 378 transactions (3077 beneficiaries) under ONOC and 510 transactions (3932 beneficiaries) in June. This has increased to 1859 transactions and 12,971 beneficiaries in July but still a very small number compared to the number of migrants in the country. ${ }^{11}$ A statement given by Mr. Paswan, the Minister for Food, "in the time of Covid-19 pandemic, the scheme

\footnotetext{
8 These calculations have been made by the author using data from FCI, budget documents and Economic Survey of India. The results were also reported in the newspaper article written by the author, as mentioned above.

9 https://www.pib.gov.in/PressReleseDetailm.aspx?PRID=1632376.

$10 \mathrm{https}: / /$ www.impds.nic.in/portal?month=7\&year=2020.

11 Based on author's analysis of data available on the integrated management of PDS portal (http://www. impds.nic.in/portal).
} 
proved immensely beneficial for migrant labourers, stranded and needy persons to access their quota of food grains through ONOC portability" 12 (emphasis added) does seem to be misplaced.

Despite all its gaps, it is evident that the PDS has played a significant role in providing relief to people in the aftermath of the national lockdown. On the other hand, the need for some support in the form of subsidised or free foodgrains to a larger population than those covered by the NFSA is vital in the present scenario where the number of Covid-19 cases is increasing and the economy continues to be in a downturn. These few months have also shown that the PDS is one of the most effective platforms through which people can be reached in the current situation. The Covid-19 survey conducted by the Azim Premji University, for instance, found that during the lockdown about $20 \%$ of vulnerable households did not receive any rations, while about $50 \%$ of households did not get a single cash transfer (Lahoti, et al. 2020) clearly showing the relative effectiveness of PDS over other relief measures. Pande et al. (2020) find in a survey in Chhattisgarh of over 3900 households where 95 per cent reported receiving rations and based on this recommend that PDS shops must provide rations to all in the present context.

\section{Beyond PDS: addressing hunger and malnutrition}

While foodgrains through the PDS do contribute to improving the situation of hunger and food security, the quantity of grains given is minimal. Further, given the scale of loss of employment and incomes, dietary diversity is also badly affected. Even in normal times, diets in India are extremely poor being largely cereal-based with very few among children as well as adults having diets that meet the dietary requirements as recommended by national and international dietary guidelines (Prasad and Sinha 2019). Such poor diets can have a debilitating impact on the nutrition status of people, especially women and children. The study by Pande et al. (2020) in Chhattisgarh finds that through the lockdown households were eating fewer fruits and vegetables. A recent study published by a team of members from the International Food Policy Research Institute (IFPRI) finds that 63-76\% of the rural poor could not afford a recommended diet in 2011 (Raghunathan et al. 2020).

The schemes aimed at improving nutrition could address this issue at least partially. The NFSA includes entitlements other than the PDS such as free meals to children below 14 years of age through mid-day meals and anganwadi centres. Pregnant and lactating women are also entitled to supplementary nutrition as well as maternity entitlements in cash of at least Rs. 6000. These schemes along with other services provided by the ICDS such as growth monitoring, immunisation, nutrition and health education make a crucial contribution to prevention and management of malnutrition.

Therefore, although data on malnutrition during this period are not available, the status of services that directly affect the food consumption of children such as school meals and anganwadi services needs to be looked at. The Supreme Court ordered that mid-day meals in schools and supplementary nutrition from ICDS for children, pregnant and lactating women must continue during the lockdown in the form of home delivery of dry rations or cash transfers. According to the provisions of NFSA as well, if for any reason these entitlements are not delivered, then a compensation in the form of a food security allowance is

12 https://www.pib.gov.in/PressReleseDetailm.aspx?PRID=1632376. 
to be paid. Moreover, the government has also stated that given the crisis, mid-day meals should be continued during the vacations as well.

Once again, there are no data on coverage of mid-day meals and supplementary nutrition, but there are a number of reports that in most states these have not been provided as schools and anganwadi centres remain closed. In Bihar, for instance, the Indian Express reported the poor state of nutrition and food consumption among Musahar children (Ghose 2020). After this, the state government had initiated distribution of foodgrains and a cash transfer for mid-day meal. In Delhi, it was found that children were given a cash transfer only for the few days in March when school was closed after which there was nothing (Iftikhar 2020). Other reports that looked at the data on offtake of foodgrains under these schemes also found a dip during the lockdown months (Varma 2020). In a survey conducted in April 2020, the Save the Children organisation found that around one-third of the sampled households reported receiving mid-day meals and over half (56\%) households reported getting take home rations from anganwadis. ${ }^{13}$

Since July, as the lockdown was lifted most state governments have also stopped providing cooked meals through feeding centres in urban areas which was an important source of nutrition, especially for the homeless and stranded migrant workers. People also require some cash in hand for buying essential commodities as well as other than other food items as the PDS gives only cereals. There is also a small quantity of pulses given under PMGKY, but the supply has been tardy. Under the PMGKY, there were also some cash transfers through advance payments under the PM-Kisan scheme and social security pensions for aged, disabled and single women. The pension beneficiaries were also given an additional amount of Rs. 1000, and all women Jan Dhan account holders were given a cash transfer of Rs. 1500. However, with all these schemes, as can be seen above the amount is very low and only those who are already included in these schemes benefit. So, the similar issues related to exclusion as discussed in relation to PDS also apply to these. Further, these additional supports were stopped once the lockdown has been lifted.

The MGNREGA is also an important intervention in the present context. While work under the scheme is now being generated, the experience so far has been that while there has been a record creation of work during the period April to July, 22\% of those who had applied for work under the scheme had not secured jobs (Pandey 2020). Under the present circumstances where a large number of migrants have returned back to rural areas, and there is a shortage of work the MGNREGA can play a very critical role in providing employment as well as boosting rural demand by putting wages into people's hands. There needs to be more research to determine how there can be some flexibility introduced into the scheme where the limit on the number of days of work given is relaxed and the requirements of registration of demand are also eased. Similarly to ensure that the food security measures are comprehensive also keeping in mind long-term objectives, there is a need for further work on decentralised procurement and procuring crops other than rice and wheat at minimum support prices (including non-timber forest produce) to simultaneously address the issue of ensuring remunerative prices for small and marginal farmers as well are contributing to diversifying the food basket of vulnerable households.

\footnotetext{
13 https://resourcecentre.savethechildren.net/library/rights-vulnerable-families-and-children-india-under -covid-19-implications-effective-response.
} 


\section{Conclusion}

The Covid-19 pandemic has brought about an unprecedented global crisis where the lives and livelihoods of millions of workers have been badly affected. With the spending on food constituting a high proportion of total expenditure of the poor, depressed incomes have had an effect on food consumption as well. In India where more than $90 \%$ of the labour force is in the informal sector and over $80 \%$ of the working people earn less than Rs. 15,000 a month (according to data from the Periodic Labour Force Survey 2018), the ability of people to manage their basic needs in the absence of current income is very low. Further, in the context of high malnutrition levels and poor dietary diversity among a large proportion of Indians even during the pre-covid times there is real danger of the country facing a severe crisis of hunger and malnutrition. Government support in the form of food and cash transfers can play a very important role in preventing such a situation from arising, and this is possible given the burgeoning food stocks in the FCI godowns. Further, an expansionary fiscal policy where the government spends more on welfare schemes such as PDS and MGNREGA can also contribute to the overall revival of the economy by putting money into the hands of people who have a high propensity to consume.

In this background, this paper looked at some of the interventions of the government towards supporting people's access to food security. The PMGKY had various measures of food and cash transfers which were all based on transfers to existing beneficiaries under various schemes. While there have been some difficulties in accessing the cash transfers due to transportation restrictions and obstacles in accessing banks, it is known that distribution of foodgrains through the PDS provided some relief.

There also gaps in these schemes that need to be addressed. First is that none of these schemes are universal and there is no effective system to reach out to those who are excluded. The thousands of migrant workers stranded in different cities, millions of households who have been excluded from 'lists' due to lack of documents, or not making the eligibility criteria or simply because 'quotas' were exhausted by the time they managed to apply had no recourse. Systems such as e-coupons put in place in Delhi have only shown that putting the onus on the poor to prove their eligibility keeps them out rather than including them. Furthermore, other interventions that are universal which could also contribute to protecting nutrition status especially of women and children such as the mid-day meals and ICDS have not been paid sufficient attention.

Although the lockdown has been eased, the economic slowdown as well as the spread of the pandemic continues. The issue of universal coverage and higher entitlements are therefore still relevant. There is need for more work on how these schemes can contribute towards some basic economic and food security for vulnerable households. Towards this, there also needs to be greater transparency where the data related to all these schemes need to be made public so that there can be concurrent independent assessments.

Funding None.

\section{Compliance with ethical standards}

Conflict of interest None. 


\section{References}

Alam M (2020) Starvation deaths resurface in Jharkhand. Down to Earth. https://www.downtoearth.org. in/news/governance/-starvation-deaths-resurface-in-jharkhand-71234 Accessed 4 Aug 2020

Centre for Equity Studies (2020) Labouring lives: hunger precarity and despair amid lockdown. A report by Centre for Equity Studies in collaboration with Delhi Research Group and Karwan-E-Mohabbat. http://centreforequitystudies.org/wp-content/uploads/2020/06/Labouring-Lives-_Final-Report.pdf. Accessed 4 Aug 2020

Dreze J (2020) Excess stocks of the Food Corporation of India must be released to the poor. Indian Express. https://indianexpress.com/article/opinion/columns/coronavirus-lockdown-food-for-poormigrants-mass-exodus-jean-dreze-6353790/ Accessed 4 Aug 2020

Drèze J, Khera R (2015) Thought for food. Outlook. https://www.outlookindia.com/magazine/story/ thought-for-food/295144 Accessed 4 Aug 2020

Drèze J, Khera R (2017) Recent social security initiatives in India. World Dev 98:555-572

Ghose D (2020) School shut, no mid-day meal, children in Bihar village back to work selling scrap. Indian Express. https://indianexpress.com/article/india/school-shut-no-mid-day-meal-children-inbihar-village-back-to-work-selling-scrap-6491830/ Accessed 4 Aug 2020

Gupta G, Kudva R, Nilekani R (2020) Digitisation makes welfare schemes possible. It can be discontinued when pandemic ends. Indian Express. https://indianexpress.com/article/opinion/columns/pradh an-mantri-garib-kalyan-yojana-pm-kisan-ujjwala-jan-dhan-6502619/ Accessed 4 Aug 2020

Hertel S (2015) Hungry for justice: social mobilization on the right to food in India. Dev Change 46(1):72-94

Himanshu, Sen A (2011) Why not a universal food security legislation. Econ Polit Wkly 46(12):16

Iftikhar F (2020) As Delhi schools remain shut, students yet to receive mid-day meal allowance since April. Hindustan Times. https://www.hindustantimes.com/cities/delhi-as-schools-remain-shutstudents-yet-to-receive-mid-day-meal-allowance-since-april/story-Zz1V3NVNaOLoiNkNTJYV nN.html Accessed 4 Aug 2020

IIPS (2017) National Family Health Survey (NFHS-4), 2015-16. International Institute for Population Sciences (IIPS), Mumbai, India

Johri A (2020) As lockdown returns, migrant families in India are going without food. Scroll. https ://scroll.in/article/967731/as-lockdown-returns-migrant-families-in-india-are-going-without-food Accessed 4 Aug 2020

Joshi A, Patnaik B, Sinha D (2017) Demanding accountability for hunger in India. In: Food riots, food rights and the politics of provisions. Routledge, pp 116-135

Khera R (2017) Impact of Aadhaar in welfare programmes. Available at SSRN 3045235

Khera (2020) Modi government's 'One Nation, One Ration' is an attempt to deflect attention from actual solutions. Scroll. https://scroll.in/article/964761/modi-governments-one-nation-one-ration-is-anattempt-to-deflect-attention-from-actual-solutions

Lahoti R, Basole A, Abraham R, Kesar S, Nath P (2020) Hunger grows as India's lockdown kills jobs: results of a survey from 12 states. The India Forum. https://www.theindiaforum.in/article/hunge r-grows-india-s-lockdown-kills-jobs. Accessed 4 Aug 2020

Pande R, Schaner S, Moore CT (2020) In times of pandemic, PDS shops should provide rations to all. Indian Express. https://indianexpress.com/article/opinion/columns/coronavirus-impact-free-ratio ns-fair-price-shops-govt-pds-scheme-6518866/. Accessed 4 Aug 2020

Pandey S (2020) Lockdown sees record spike in NREGA jobs, but 1.7 crore applicants fail to get one. The Print. https://theprint.in/india/governance/lockdown-sees-record-spike-in-nrega-jobs-but-1-7crore-applicants-fail-to-get-one/460818/. Accessed 4 Aug 2020

Prasad V, Sinha D (2019) Dietary deprivation: diets sans diversity. Frontline magazine. https://frontline. thehindu.com/cover-story/article29766073.ece. Accessed 4 Aug 2020

Raghunathan K, Headey D, Herforth A (2020) Affordability of nutritious diets in rural India. Food Policy 101982

Ramakumar R (2020) Introduction: the impact of the Covid-19 pandemic. Rev Agrar Stud 10(1). http:// ras.org.in/7a765640cf1a4efde60276269e0f7b2d Accessed 4 Aug 2020

Scroll (2020) 100 million Indians fall through gaps in food safety net, economists urge rethink on Covid19 relief. https://scroll.in/article/959235/100-million-indians-fall-through-gaps-in-food-safety-neteconomists-urge-rethink-on-covid-19-relief. Accessed 4 Aug 2020

Sen P (2020) The Covid-19 shock: learnings from the past, addressing the present (part I-V). Ideas for India. https://www.ideasforindia.in/topics/macroeconomics/the-covid-19-shock-learnings-fromthe-past-addressing-the-present-i.html 
Sharma, H. (2020). Only $13 \%$ of allocated free food grain handed out to returning migrant workers, reveals govt data. Indian Express. https://indianexpress.com/article/india/only-13-of-allocated-free-food-grain -handed-out-to-returning-migrant-workers-reveals-govt-data-6485982/. Accessed 4 Aug 2020

Sinha D (2020a) That foodgrain stocks lie in public godowns while people are going hungry is a scandal. Indian Express. https://indianexpress.com/article/opinion/columns/india-coronavirus-lockdown-foodstock-supply-pds-scheme-6476514/. Accessed 4 Aug 2020

United Nations (2020) Policy brief: the impact of COVID-19 on food security and nutrition. https://in.one. un.org/wp-content/uploads/2020/06/SG-Policy-Brief-on-COVID-Impact-on-Food-Security.pdf. Accessed 4 Aug 2020

Varma S (2020) How the lockdown destroyed children's nutrition programmes. Newsclick. https://www. newsclick.in/How-the-Lockdown-Destroyed-Children-Nutrition-Programmes. Accessed 4 Aug 2020

World Bank (2020) Global economic prospects, June 2020. Washington, DC: World Bank. ( World Bank. https://openknowledge.worldbank.org/handle/10986/33748. Accessed 4 August 2020. License: CC BY 3.0 IGO

Publisher's Note Springer Nature remains neutral with regard to jurisdictional claims in published maps and institutional affiliations. 